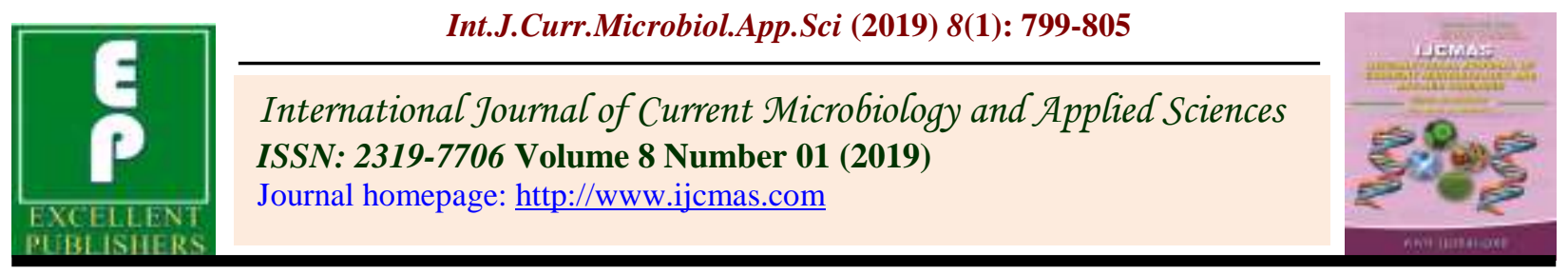

Original Research Article https://doi.org/10.20546/ijcmas.2019.801.087

\title{
Rootstock Affects Graft Success, Growth and Physiological Parameters of Grape Varieties (Vitis vinifera L.)
}

\author{
V.S. Ghule ${ }^{1 *}$, P.M. Zagade ${ }^{2}$, V.A. Bhor ${ }^{2}$ and R.G. Somkuwar ${ }^{2}$ \\ ${ }^{1}$ Mahatma Phule Krishi Vidyapeeth, Rahuri, India \\ ${ }^{2}$ National Research Centre for Grapes, Pune, India
}

*Corresponding author

\section{A B S T R A C T}

\section{Keywords}

Rootstock, Growth parameters,

Physiological parameter, Graft success, Stock:scion ratio

Article Info

Accepted:

07 December 2018

Available Online:

10 January 2019
A field experiment was conducted to study the effect of different rootstocks (Dogridge, 110R, 140Ru and 1103P) on growth and physiological parameters in Crimson Seedless, Manjari Naveen and Nanasaheb Purple. Growth parameters such as trunk girth, number of canes and leaf area showed the significant difference while stock:scion ratio, graft success showed non-significant difference among the cultivars. However, physiological parameters such as transpiration rate and assimilation rate showed non-significant difference in Crimson Seedless and Manjari Naveen while in Nanasaheb Purple it showed significant difference. Stomatal conductance showed the significant difference in all the three cultivars. The present study revealed that among all rootstocks, Dogridge and 1103P performed well for vegetative growth and physiological parameters.

\section{Introduction}

Grape (Vitis vinifera L.) is one of the most important fruit crops of temperate zone, acclimatized to sub-tropical and tropical agro climatic conditions in India. The major grape growing states are Maharashtra (83.5\%), Karnataka (11.7\%), Andhra Pradesh (0.3\%), Punjab (2\%) and Tamil Nadu (1.8\%), Telangana (1\%) amounting to nearly 90 per cent of the total production (Anonymous,2016). The area under grapes during 2016-17 was 1.37 lakh hectares with production of 2922 million tonnes (Anonymous, 2017). In spite of increasing occurrence of soil salinity, drought, and declining productivity of grape, the use of suitable rootstocks became imperative (Singh and Sharma, 2005). The use of rootstocks have recently gained importance as the only effective and successful strategy to combat abiotic and biotic stresses in major grape growing countries worldwide (Troncoso et al., 1999). However, the choice of specific rootstock is becoming increasingly difficult as a result of the availability of numerous new 
rootstocks (Loreti and Massai, 2006). A rootstock found to be beneficial for one cultivar may not be universally advantageous for others, as the interaction of stock and scion influence the vine performance more than the stock scion alone (Hartmann et al., 1993).Rootstocks perform differently with different soils and climates, thus regional rootstock evaluations are essential in determining which rootstock is best suited to a particular environment (Shaffer, 2002).

Rootstock affects the growth parameters significantly and which can be varying from cultivar to cultivar (Kose et al., 2014). There is also an important role of rootstock compatibility with different grapevines (Richards 1983; Vrsic et al., 2004). The interactions between rootstocks and varieties have an important effect on the varieties vigour and productivity (Boselli et al., 1992; Ferroni and Scalabrelli, 1995; Keller et al., 2001).Rootstock also affects the resistance of scions by regulating some physiological and morphological properties (Ulas et al., 2014).

The effect of rootstocks on gas exchange parameters is scion specific (Bica et al., 2000). Rootstocks influences the vegetative growth their by increasing the photosynthesis of vine (Somkuwar et al., 2015) and it plays key role on leaf gas exchange with changes in net assimilation parameters, stomatal conductance and transpiration rate (Brown et al., 1985; Bavaresco and Lovisolo, 2000).Considering the benefits of rootstocks and aiming increasing the efficiency of scion cultivars, the experiment was conducted using three grape varieties grafted on different rootstocks.

\section{Materials and Methods}

The trial was conducted at the farm of ICARNational Research Centre for Grapes, Pune during 2018-19. The experimental site is situated in Mid-West Maharashtra at an altitude of $559 \mathrm{~m}$ above mean sea level; $\left(18.32^{\circ} \mathrm{N}\right.$ and $\left.73.51^{\circ} \mathrm{E}\right)$. The rootstocks Dogridge, 110R, 140Ru and 1103P were planted in January 2017 at a distance of $9 \times 5$ feet. The rootstocks were maintained in the field following standard recommended cultural practices. The grape varieties i.e., Crimson Seedless, Manjari Naveen and Nanasaheb Purple were grafted in August 2017 and trained to expanded Y- Trellis. The observations recorded were as below.

Stock: scion ratio: The girth of rootstock was measured one $\mathrm{cm}$ below the graft union while the scion girth was measured one $\mathrm{cm}$ above the graft union with the help of digital Vernier calliper.

Trunk girth (mm): The trunk girth was measured at a point where two arms were separated with the help of digital vernier calliper.

Number of canes: The number of canes per vinewas counted at cane maturity and mean was recorded.

Graft success (\%): The percent graft success was calculated by using the formula given below.

No. of successful grafts

Graft success $(\%)=$

Total no. of rootstocks grafted

Leaf area: Leaf area was measured by linear method (LBK method) expressed in $\mathrm{cm}^{2}$. The mathematical relationship for calculation was given as follows

Leaf area $(A)=L \times B \times K(0.810)$

Physiological parameters: A fully opened fifth leaf from apex was selected to measure gas exchange parameters with the help of an infra-red gas analyser (Li 6400, LI-COR Biosciences, Linacoln, Nebraska, USA). 


\section{Statistical analysis}

The experiment was conducted in Randomized Block Design (RBD) consisting of four treatments as rootstocks which were replicated five times. Statistical analysis of data collected during the course of studies was carried out by standard method of analysis of variance as described by Panse and Sukhatme (1995). The standard error of mean (S.Em \pm ) was worked out and the critical difference at 5 per cent and 1 per cent level of significance was calculated wherever the results were found significant.

\section{Results and Discussion}

\section{Growth parameters}

The data on effect of different rootstocks on growth parameters are presented in Table 1. In Crimson Seedless, maximumstock scion ratio was recorded in 1103P rootstock while minimum in Dogridge rootstock. In Manjari Naveen grafted vines, maximum stock:scion ratio was obtained on $110 \mathrm{R}$ and minimum on 140Ru rootstock. In Nanasaheb Purple maximum stock scion ratio was recorded on Dogridge and $140 \mathrm{Ru}$ and minimum was recorded on 1103P rootstocks. Among the three varieties maximum stock scion ratio was recorded in Nanasaheb purple grafted on Dogridge rootstock while minimum was recorded in Manjari Naveen grafted on 140Ru rootstock. The stock scion ratio nearing 1.00 will have uniform girth of both stock scion (Somkuwar et al., 2015). The variations among the stock: scion ratio of same cultivar grafted on different rootstocks might be due to the difference in the physiology of the rootstocks and their responses to the various soil conditions. Somkuwar et al., (2006) reported higher stock:scion ratio in Flame Seedless grafted on different rootstocks while Satishaet al., (2010) found that there is no adverse effects of different rootstocks in Thompson Seedless grapes.
Trunk girth showed significant difference among three varieties. In Crimson Seedless, maximum trunk girth was observed on Dogridge rootstock while minimum on 1103P rootstock. In Manjari Naveen, maximum trunk girth was observed on 140Ru and minimum on 110R rootstock. In Nanasaheb Purple, maximum trunk girth was recorded on 1103P and minimum in Dogridge rootstock. Among the three varieties maximum trunk girth was recorded in Crimson Seedless grafted on Dogridge rootstock while minimum was noticed in Nanasaheb Purple grafted on Dogridge rootstock. It might be due to more stored carbohydrates of scion and higher root activity of rootstocks. Reddy (1987) also reported maximum trunk girth in Anab-EShahi grafted on Dogridge and on Gulabi rootstocks.

It was observed that rootstocks had significant influence on number of canes in Crimson Seedless and Manjari Naveen. Maximum numbers of canes were obtained on 1103P rootstock compared to minimum on 110R rootstock while in Nanasaheb Purple maximum numbers of canes were obtained on $1103 \mathrm{P}$ rootstock compared to minimum on Dogridge rootstock.

Among all the varieties, Crimson Seedless grafted on $1103 \mathrm{P}$ rootstock produced maximum number of canes per vine compared to minimum in Nanasaheb Purple grafted on Dogridge rootstock. The production of canes depends upon vigour of the vine and rootstock which in turn depends upon the extent of stored food material in the vine. Vigorous varieties having greater stored food material produce higher number of canes (Menora, 2014).

Satisha et al., (2010) noticed that the highest numbers of cane were recorded on Dogridge rootstock during most years of the study, while it was least on own rooted vines and on the $1103 \mathrm{P}$ rootstock. 
The rootstocks did not affect the graft success in all varieties. However, among all the cultivars maximum graft success was recorded in Manjari Naveen grafted on 1103P and minimum in Nanasaheb Purple grafted on Dogridge rootstock. Higher percentage of survival of grafts might be due to active growing meristematic stage exhibited by both the rootstock and scion, which facilitates callus formation and thereby enhances grafting success (Stino et al., 2011). Errea (1998) also reported insufficient callus growth, defects in phloem differentiation, lignification or metabolic interaction. However, Lu and Ren (2008) and Stino et al., (2009) reported variation in percentage success and survival of grape grafting due to the use of rootstocks.

Among the different rootstocks, leaf area varied significantly. Crimson Seedless recorded maximum leaf area on 140Rugrafted vines while minimum was recorded on Dogridge rootstock.

In Manjari Naveen, maximum leaf area was obtained on Dogridge and minimum on 140Ru rootstock. In Nanasaheb Purple, maximum leaf area was recorded on Dogridge while minimum on 1103P rootstock. Among all varieties maximum leaf area was recorded in Manjari Naveen grafted on Dogridge rootstock and minimum in Nanasaheb Purple grafted on $1103 \mathrm{P}$ rootstock. The early sprouting was responsible for more number of leaves, in turn gave rise to more photosynthesis which might have increased the leaf area at greater extent in later growth stages (Sridhar, 2014). Bica et al., (2000) observed that there is significant effect of use of rootstock on maximum leaf area.

\section{Physiological parameters}

The data on Effect of different rootstocks on photosynthetic activity of different grape varieties are presented in Table 2. The rootstock 140Ru recorded maximum transpiration rate while minimum in Dogridge, 110R and Dogridge rootstock respectively. Among the three cultivars, maximum transpiration rate was recorded in Nanasaheb Purple grafted on $140 \mathrm{Ru}$ while minimum in Manjari Naveen grafted on 110R rootstock.

It was observed that rootstock had nonsignificant effect on assimilation rate in Crimson Seedless, Manjari Naveen and Nanasaheb Purple. The maximum assimilation rate was recorded on $1103 \mathrm{P}, 140 \mathrm{Ru}$ and Dogridge rootstock respectively whereas minimum was recorded on $110 \mathrm{R}$ rootstock. Among all the varieties, highest assimilation rate was noticed in Nanasaheb Purple grafted on Dogridge rootstock while minimum in Crimson Seedless grafted on 110R. Stomatal conductance is an important factor in physiological parameters.

The rootstocks showed significant effect on stomatal conductance. The grape varieties Crimson Seedless, Manjari Naveen and Nanasaheb Purple recorded maximum stomatal conductance on $1103 \mathrm{P}, 140 \mathrm{Ru}$ and $1103 \mathrm{P}$ respectively while minimum on $110 \mathrm{R}$ and Dogridge rootstock. Among all the varieties, maximum stomatal conductance was recorded in Nanasaheb Purple grafted on 1103P while lowest in Nanasaheb Purple grafted on Dogridge rootstock. The rate of transpiration, stomatal conductance and assimilation rate might be influenced by rootstock genotype, root system, vine vigour and scion characteristics (Somkuwar et al., 2015). Bica et al., (2000) reported that scion foliar biomass and leaf area might be responsible for alteration in the gas exchange parameters. They found significant effect of rootstock on leaf area, transpiration rate, stomatal conductance and assimilation rate while Chardonnay vines grafted on SO4 rootstock showed lower photosynthesis, stomatal conductance, and transpiration rate than those grafted on 1103P rootstock. 
Table.1 Effect of different rootstocks on growth parameters of grape varieties

\begin{tabular}{|c|c|c|c|c|c|c|c|c|c|c|c|c|c|c|c|}
\hline \multirow{2}{*}{ Rootstocks } & \multicolumn{5}{|c|}{ Crimson Seedless } & \multicolumn{5}{|c|}{ Manjari Naveen } & \multicolumn{5}{|c|}{ Nanasaheb Purple } \\
\hline & $\begin{array}{l}\text { Stock: } \\
\text { scion } \\
\text { ratio }\end{array}$ & $\begin{array}{l}\text { Trunk } \\
\text { girth } \\
(\mathrm{mm})\end{array}$ & $\begin{array}{l}\text { No. of } \\
\text { canes } \\
\text { /vine }\end{array}$ & $\begin{array}{c}\text { Graft } \\
\text { success } \\
(\%)\end{array}$ & $\begin{array}{l}\text { Leaf } \\
\text { area } \\
\left(\mathrm{cm}^{2}\right)\end{array}$ & $\begin{array}{l}\text { Stock: } \\
\text { scion } \\
\text { ratio }\end{array}$ & $\begin{array}{l}\text { Trunk } \\
\text { girth } \\
(\mathrm{mm})\end{array}$ & $\begin{array}{l}\text { No. of } \\
\text { canes } \\
\text { /vine }\end{array}$ & $\begin{array}{c}\text { Graft } \\
\text { success } \\
(\%)\end{array}$ & $\begin{array}{l}\text { Leaf } \\
\text { area } \\
\left(\mathrm{cm}^{2}\right)\end{array}$ & $\begin{array}{l}\text { Stock: } \\
\text { scion } \\
\text { ratio }\end{array}$ & $\begin{array}{l}\text { Trunk } \\
\text { girth } \\
(\mathrm{mm})\end{array}$ & $\begin{array}{l}\text { No. of } \\
\text { canes } \\
\text { /vine }\end{array}$ & $\begin{array}{c}\text { Graft } \\
\text { success } \\
(\%)\end{array}$ & $\begin{array}{l}\text { Leaf } \\
\text { area } \\
\left(\mathrm{cm}^{2}\right)\end{array}$ \\
\hline Dogridge & 1.00 & 26.98 & 8.24 & 85 & 122.46 & 0.92 & 22 & 8.53 & 95 & 157.81 & 1.05 & 15.66 & 5.32 & 70 & 136.20 \\
\hline $110 \mathrm{R}$ & 1.03 & 23.84 & 7.06 & 95 & 132.30 & 0.95 & 19.52 & 6.86 & 87.5 & 151.85 & 1.01 & 18.5 & 6.24 & 82.5 & 133.00 \\
\hline 140Ru & 1.03 & 24.58 & 8.56 & 85 & 137.42 & 0.90 & 23.96 & 7.96 & 82.5 & 145.93 & 1.05 & 17.86 & 5.48 & 72.5 & 135.53 \\
\hline 1103P & 1.04 & 20.74 & 10.92 & 95 & 127.85 & 0.92 & 23.4 & 9.52 & 97.5 & 149.96 & 0.98 & 19.94 & 7.46 & 92.5 & 120.92 \\
\hline SEm \pm & 0.032 & 1.38 & 0.87 & 3.54 & 3.06 & 0.02 & 0.91 & 0.41 & 5.75 & 2.53 & 0.04 & 0.88 & 0.52 & 4.28 & 2.07 \\
\hline $\begin{array}{c}\text { C.D. at } 5 \\
\%\end{array}$ & 0.10 & 4.24 & 2.67 & 10.89 & 9.44 & 0.07 & 2.80 & 1.27 & 17.72 & 7.81 & 0.13 & 2.72 & 1.59 & 13.19 & 6.36 \\
\hline Sig & NS & $*$ & * & NS & $*$ & NS & $*$ & $* *$ & NS & $*$ & NS & $*$ & $*$ & $*$ & $* *$ \\
\hline
\end{tabular}

$*=$ significant at 0.05 level, $* *=$ significant at 0.01 level

Table.2 Effect of different rootstocks on physiological parameters of grape varieties

\begin{tabular}{|c|c|c|c|c|c|c|c|c|c|}
\hline \multirow[t]{2}{*}{ Rootstocks } & \multicolumn{3}{|c|}{ Crimson Seedless } & \multicolumn{3}{|c|}{ Manjari Naveen } & \multicolumn{3}{|c|}{ Nanasaheb Purple } \\
\hline & $\begin{array}{c}\text { Transpiration } \\
\text { Rate (mmol m-2 } \\
\text { s-1) }\end{array}$ & $\begin{array}{l}\text { Assimilation } \\
\text { Rate ( } \mu \text { mol } \\
\mathrm{m}-2 \mathrm{~s}-1)\end{array}$ & $\begin{array}{c}\text { Stomatal } \\
\text { Conductance }\end{array}$ & $\begin{array}{l}\text { Transpiration } \\
\text { Rate (mmol } \\
\text { m-2 s-1) }\end{array}$ & $\begin{array}{l}\text { Assimilation } \\
\text { Rate }(\mu \mathrm{mol} \\
\mathrm{m}-2 \mathrm{~s}-1)\end{array}$ & $\begin{array}{c}\text { Stomatal } \\
\text { Conductance }\end{array}$ & $\begin{array}{l}\text { Transpiration } \\
\text { Rate (mmol } \\
\text { m-2 } \mathrm{s}-1)\end{array}$ & $\begin{array}{l}\text { Assimilation } \\
\text { Rate ( } \mu \text { mol m- } \\
2 \mathrm{~s}-1)\end{array}$ & $\begin{array}{c}\text { Stomatal } \\
\text { Conductance }\end{array}$ \\
\hline Dogridge & 1.92 & 9.74 & 65.5 & 1.83 & 9.89 & 67.4 & 1.76 & 10.31 & 54.1 \\
\hline $110 R$ & 2.17 & 8.87 & 61.5 & 1.54 & 9.45 & 61.8 & 1.95 & 9.40 & 70.5 \\
\hline 140Ru & 2.26 & 9.62 & 71.6 & 1.98 & 10.18 & 75.2 & 2.42 & 9.52 & 72.4 \\
\hline 1103P & 2.06 & 10.18 & 78.3 & 1.90 & 9.71 & 64.8 & 2.12 & 9.53 & 82.8 \\
\hline SEm \pm & 0.09 & 0.39 & 1.13 & 0.14 & 0.25 & 2.9373 & 0.10 & 0.11 & 1.31149 \\
\hline $\begin{array}{l}\text { C.D. at } 5 \\
\%\end{array}$ & 0.28 & 1.19 & 3.48 & 0.43 & 0.78 & 9.05 & 0.31 & 0.34 & 4.04 \\
\hline Sig & NS & NS & $* *$ & NS & NS & $*$ & $* *$ & $* *$ & $* *$ \\
\hline
\end{tabular}

$*=$ significant at 0.05 level, $* *=$ significant at 0.01 level 
In conclusion from the above investigation it is concluded that Crimson Seedless showed good performance on 1103P for parameters like stock: scion ratio, number of canes, graft success, assimilation rate and stomatal conductance while $140 \mathrm{Ru}$ for leaf area and transpiration rate. In Manjari Naveen 1103P showed good performance on growth parameters while $140 \mathrm{Ru}$ showed better performance on physiological parameters. However, in Nanasaheb Purple, 1103P performed better for growth parameters while Dogridge for physiological parameters. Overall performance on graft success among the rootstocks showed that Dogridge and $1103 \mathrm{P}$ were better for these varieties.

\section{References}

Anonymous. 2016. National Horticulture board, database 2016.

Anonymous. 2017. Horticulture Statistics at a Glance. Horticulture Statistics Division, DAC \& FW, GOI, pp.1-514.

Bavaresco, L., Lovisolo, C. 2000. Effect of grafting on grapevine chlorosis and hydraulic conductivity. Vitis 39, 8992.

Bica, D., Gay, G., Morando, A., Soave, E. and Bravdo, B. A. 2000. Effects of rootstock and Vitis vinifera genotype on photosynthetic parameters. Acta Hort. 526:373-379.

Boselli, M., Fregoni M., Vercesi A., Volpe, B. (1992). Variation in mineral composition and effects on the growth and yield of Chardonnay grapes on various rootstocks. Agricoltura Ricerca, 14: 138-139.

Brown, C. S., Young, E., Pharr, D. M. 1985. Rootstocks and scion effect on carbon partitioning in apple leaves. J. Am. Soc. Hortic. Sci. 110, 701-705.

Errea, P. 1998. Implications of phenolic compounds in graft incompatibility in fruit tree species. Scientia
Horticulturae.74:195-205.

Ferroni, G., Scalabrelli, G. (1995). Effect of rootstock on vegetative activity and yield in grapevine. Acta Horticulturae, 388: 37-42.

Hartman, H.T., Kester, D.E., Davis, J.F.T. and Robert, L.G. 1993. Techniques of grafting, p. 772-780. In: Plant propagation: Principles and practices, 6th edition Prentice Hall Pvt. Ltd., New Delhi.

Keller, M., Kummer, M., Vasconcelos, M. (2001). Reproductive growth of grapevine in response to nitrogen supply and rootstock. Australian Journal of Grape and Wine Research, 7: 12-18.

Kose, B., Karabulut, B. and Ceylan, K. 2014. Effect of rootstock on grafted grapevine quality. Europ. J. Hort. Sci., 79 (4), 197-202.

Loreti, F. and Massai, R. 2006. State of the art on peach rootstocks and orchard systems. Acta Hort., 713:253-268.

Lu, J. and Ren, Z. 2008. Evaluation of grape rootstocks for resistance to Pierce's Disease and adaptation to north Florida environment. Acta Hort. 772: 257-261.

Menora, B. N. (2014). Studies on the effect of different rootstocks on growth, yield, raisin recovery and quality of commercial grape varieties. A M.Sc. thesis submitted to Dr. Y.S.R. Horticultural University, Hydrabad.

Panse, V. G. and Sukhatme, P. V. (1995). Statistical Methods for Agricultural Workers. ICAR Rev. Ed. pp. 97-156.

Reddy, B. M. C. 1987. Investigation on effect of rootstocks in Anab-e-Shahi grapes (Vitis venifera L.). Ph.D. Thesis submitted to UAS, Banglore.

Richards D. (1983): The grape root system. Horticultural Reviews, 5: 127-168.

Satisha, J., Somkuwar, R.G., Sharma, J., Upadhyay, A.K. and Adsule, P.G. 
2010. Influence of rootstocks on growth, yield and fruit composition of Thompson Seedless grapes grown in Pune region of India. S. Afr. J. Enol. Vitic. 31(1):1-8.

Shaffer, R.G. 2002. The Effect of Rootstock on the Performance of the Vitis vinifera Cultivars Pinot noir, Chardonnay, Pinot Gris and Merlot. A thesis submitted to Oregon State University, United States.

Singh, M. and Sharma, J.K. 2005. Effect of rootstocks on disease intensity of Perlette Grape vine. Haryana J. Hortic. Sci., 34:234-235.

Somkuwar, R. G., Taware, P. B., Bhange, A. M., Sharma, J. and Khan, I. 2015. Influence of different rootstocks on growth, photosynthesis, biochemical composition, and nutrient contents in 'Fantasy Seedless' grapes. International Journal of Fruit Science, 00:1-16.b

Somkuwar, R.G., Satisha, J., Ramteke, S.D. and Mundankar, K. 2006. Effect of different rootstocks on graft success in Flame Seedless grapes. J. Prod. Protec. 2(1): 63- 64.

Stino, R.G., Mohsen, A.T., Rizk, I.A. and Mahmoud, Y.A. 2009. Performances of some grape cultivar grafted on different rootstocks and some factors affecting success. J. Bio. Chem. Environ. Sci. 4:241-256.

Stino, R.G., Ghoneim, I.E., Marwad, I.A., and Fadl., T.R. 2011. Performance of summer grafted Superior seedless grape grafts on different rootstocks. $J$. Hort. Sci. Ornamental Plants. 3(1):86-90.

Sridhar, R. (2014). Effect of season on the success and growth of mango (Mangifera indica L.) softwood grafts under southern transitional zone of Karnataka. Environment and Ecology, 32(4B): 1717-1719.

Troncoso, A., Atti, C.M. and Cantos, M. 1999. Evaluation of salt tolerance of in vitro grown grapevine rootstock varieties. Vitis, 38(2):55-60.

Ulas S., Guler A. and Candemir A. (2014). Effect of rootstocks on different physiological parameters in some grape cultivars. Turkish Journal of Agricultural and natural sciences, (1): 1097-1100.

Vrsic, S., Valdhuber J., Pulko B. (2004): Compatibility of the rootstock Borner with various scion varieties. Vitis, 43: $155-156$.

\section{How to cite this article:}

Ghule, V.S., P.M. Zagade, V.A. Bhor and Somkuwar, R.G. 2019. Rootstock Affects Graft Success, Growth and Physiological Parameters of Grape Varieties (Vitis vinifera L.). Int.J.Curr.Microbiol.App.Sci. 8(01): 799-805. doi: https://doi.org/10.20546/ijcmas.2019.801.087 